Article

\title{
Chemical Stability and Leaching Behavior of One-Part Geopolymer from Soil and Coal Fly Ash Mixtures
}

\author{
April Anne S. Tigue ${ }^{1}$, Roy Alvin J. Malenab ${ }^{1}$, Jonathan R. Dungca ${ }^{2} \mathbb{D}$, Derrick Ethelbhert C. Yu ${ }^{3}$ \\ and Michael Angelo B. Promentilla 1,*D \\ 1 Chemical Engineering Department, Gokongwei College of Engineering, De La Salle University, Manila 1004, \\ Philippines; april_tigue@dlsu.edu.ph (A.A.S.T.); roy.malenab@dlsu.edu.ph (R.A.J.M.) \\ 2 Civil Engineering Department, Gokongwei College of Engineering, De La Salle University, Manila 1004, \\ Philippines; jonathan.dungca@dlsu.edu.ph \\ 3 Chemistry Department, College of Science, De La Salle University, Manila 1004, Philippines; \\ derrick.yu@dlsu.edu.ph \\ * Correspondence: michael.promentilla@dlsu.edu.ph; Tel.: +63-02-536-0223
}

Received: 15 July 2018; Accepted: 13 September 2018; Published: 18 September 2018

\begin{abstract}
Aluminosilicate minerals have become an important resource for an emerging sustainable material for construction known as geopolymer. Geopolymer, an alkali-activated material, is becoming an attractive alternative to Portland cement because of its lower carbon footprint and embodied energy. However, the synthesis process requires typically a two-part system for alkali activation wherein the solid geopolymer precursor is mixed with aqueous alkali solutions. These alkali activators are corrosive and may be difficult to handle in the field-scale application. In this study, a one-part geopolymer in which coal fly ash was mixed with solid alkali activators such as sodium hydroxide and sodium silicate to form a powdery cementitious binder was developed. This binder mixed with soil only requires water to form the soil-fly ash (SO-CFA) geopolymer cement, which can be used as stabilized soil for backfill/foundation. This geopolymer product was then evaluated for chemical stability by immersing the material with $5 \%$ by weight of sulfuric acid solution for 28 days. Indication suggests that the geopolymer exhibited high resistance against acid attack with an observed increase of unconfined compressive strength even when the immersion time in acidic solution was increased to 56 days. The mineralogical phase, microstructure, and morphology of the material were characterized by X-ray diffraction (XRD), Fourier transform infrared (FTIR) spectroscopy, and scanning electron microscopy with energy-dispersive X-ray spectroscopy (SEM-EDX), respectively. Results not only confirmed the formation of gypsum due to acid attack but also indicated the dissolution of anorthite and albite that may have caused the microstructure to be composed of sodium aluminosilicate hydrate (N-A-S-H) and calcium (alumino) silicate hydrate (C(-A)-S-H) with poly(ferro-sialate-siloxo) and poly(ferro-sialate-disiloxo) networks. A column leaching test with deionized water was also performed on the soil-fly ash geopolymer to study the leachability of metals in the material. Results showed that arsenic exhibits higher mobility in the geopolymer as compared to that of cadmium, chromium, and lead.
\end{abstract}

Keywords: acid resistance; leachability; one-part geopolymer soil stabilizer; soil; coal fly ash; alkali activation

\section{Introduction}

The construction industry contributes to about one-third of the energy-related global $\mathrm{CO}_{2}$ emissions which makes it a significant sector often targeted as part of the mitigation strategies to 
reduce carbon footprint [1]. In addition, one of the important materials in the construction industry is Portland cement where it is used as a binder. The production of cement accounts for 5-8\% of global anthropogenic emissions [2]. With a local cement demand amounting to 24.4 million tons in 2015 and $20 \%$ public construction growth rate, the forecast for cement may continue to increase for the coming years [3]. Carbon dioxide emissions from cement production come from the calcination process to produce clinker and from the combustion of fuel used for heating. Several efforts have been made to reduce its consumption such as blending of other pozzolanic and cementitious materials to reduce clinker consumption, and utilization of agricultural waste as an alternative source of fuel. With the pressure of the international laws and agreement toward sustainability, the reduction of $\mathrm{CO}_{2}$ particularly in this industry remains a challenge. Hence, several approaches have been proposed to reduce the cement consumption. This includes the use of industrial by-products with high content of aluminosilicate minerals as a potential alternative to construction material. For example, coal fly ash which is an industrial by-product of thermal power plants becomes an important resource for blended cement. In the Philippines, about 3 million metric tons (MMT) of coal ash is produced annually [4,5], while only a quarter of 750 MMT being generated worldwide is being valorized [6].

Aluminosilicate minerals have also gained a great deal of interest as a precursor in emerging geopolymer products such as cement, concrete, bricks, foam, and composite [7-15]. With the presence of alkaline activating solutions, these aluminosilicate minerals become reactive and then form into aluminosilicate oligomers. Through polycondensation, these turn into a hardened 3D molecule network which is then called geopolymer. Geopolymer also referred to as an alkali-activated material, is used as a binder system similar to Portland cement that hardens at room temperature [16]. Aside from having a lower carbon footprint as compared with Portland cement, these materials exhibit good mechanical properties such as high early strength, excellent resistance to acid, and exceptional resistance to immersion [17-19]. Curing at an elevated temperature also helps accelerate the early strength development of geopolymers $[15,20]$.

However, the traditional synthesis known as the two-part geopolymer which is typically cured at an elevated temperature system is difficult to implement in field scale applications [21,22]. In contrast to that of ordinary Portland cement (OPC) which only requires water, corrosive alkali solutions are prepared first and then mixed with the solid geopolymer precursor to form the binder in a two-part geopolymer system. On the other hand, a one-part geopolymer-based binder system uses a dry mix that consists primarily of solid aluminosilicate precursors and solid alkali sources to which water is added, similar to the OPC binder system. In terms of the environmental impacts of geopolymer-based binder systems, an average reduction of $24 \%$ for one-part geopolymers and $60 \%$ for two-part geopolymers in comparison to OPC were reported in [23]. Although curing at an elevated temperature could improve the early strength development, curing at room temperature will reduce the embodied energy of the product as defined by its fit to purpose. Note that several studies reported that geopolymerization can still occur even if cured at an ambient condition [16,20,22-24]. Previous studies have also reported the potential of two-part geopolymer binder systems as soil stabilizer for geotechnical engineering applications $[17,24]$, but the next-generation soil stabilizer based on a one-part geopolymer system has not been well explored particularly in the Philippines. This study thus proposes a novel one-part system that combines soil and coal fly ash mixture with solid alkali activator to form soil-fly ash (SO-CFA) geopolymer cement at ambient curing conditions. By "just adding water", a geopolymeric binder that can be used as a soil stabilizer for backfill/foundation is produced.

We also investigated the chemical stability and leaching behavior of soil-fly ash (SO-CFA) geopolymer cement. Limited studies have evaluated the acid resistance of two-part geopolymer [19,25], and none have yet reported the stability under acid immersion of one-part geopolymer from soil-fly ash mixtures. Problems may also arise with the utilization of coal fly ash as it has been known to leach toxic heavy metals under certain conditions [26-28]. It is therefore imperative to study the leachability of these heavy metals from the geopolymer matrix. 


\section{Materials and Methods}

\subsection{Sources of Raw Materials}

Coal fly ash (CFA) and soil (SO) samples used in this study were obtained from a coal-fired power plant located at the central region of Luzon, Philippines, and were collected from a construction site located in the southern part of Manila, Philippines, respectively. CFA samples were used as received while the $\mathrm{SO}$ samples were immediately sieved using Mesh No. 4. Chemical reagents such as sodium silicate (SS) with composition $44 \% \mathrm{SiO}_{2}$, sodium hydroxide (SH) micro pearls with $99 \%$ purity, and sulfuric acid with $95 \%$ purity were purchased locally and used in the study.

\subsection{Characterization of Raw Materials}

Characterization techniques such as chemical analysis, particle size analysis, Unified Soil Classification System (USCS), specific gravity, and Atterberg limits were taken into consideration. Chemical analyses of fly ash and soil were performed using X-ray fluorescence dispersive (XRF, Shimadzu Model EDX-720, Shimadzu Corp., Kyoto, Japan), X-ray diffractometer (XRD, Multiflex Rigaku Automated Powder X-ray Diffractometer, Rigaku Corp., Tokyo, Japan), and Fourier transform infrared (FTIR, Thermo Nicolet FT-IR Spectrometer 6700, Thermo Fisher Scientific, Waltham, MA, USA) spectroscopy. Elemental analysis was performed by irradiating the sample with $\mathrm{X}$-ray beams generated from a voltage of $50 \mathrm{kV}$ and a current of $35 \mathrm{~A}$ using X-ray fluorescence (XRF) instrument. For particle size analysis of CFA, dynamic light scattering was considered with a single exposure and a total exposure time of $10 \mathrm{~s}$ using sodium lauryl sulfate as a solvent. The particle size of the soil was determined using sieve analysis in accordance with ASTM D-422 procedure. The specific gravity was determined using the method specified in ASTM D-854. The Atterberg limit, which includes the plastic limit and the liquid limit of soil, was determined in accordance with ASTM D-4318. The soil type was determined based on a unified soil classification system (USCS) using the data obtained from the Atterberg limit and particle size distribution.

\subsection{One-Part Geopolymer Synthesis}

A mixture of coal fly ash (CFA), soil (SO), and alkali activator equivalent to $22.58 \%$ CFA, $67.74 \%$ SO, $4.84 \% \mathrm{SH}$, and $4.84 \%$ SS was prepared [29]. One-part geopolymer binder was made by adding water to the dry mixture of CFA, SH, and SS using a 0.17 water/dry mixture ratio. This one-part geopolymer binder was then mixed with soil. The soil-geopolymer was then compacted in a 50 mm diameter by a $100 \mathrm{~mm}$ height cylindrical mold for 3 layers of about 25 tamps per layer. The molded samples, one control and two experimental, were sealed and cured for 28 days under ambient conditions. The control sample (SO-CFA) was then characterized for unconfined compressive strength (UCS), XRD, FTIR, and SEM-EDX analyses. The compressive strength of soil-fly ash geopolymer cement was measured using Digimax Uniframe Loading with a displacement speed of $0.05 \mathrm{~mm} / \mathrm{min}$. On the other hand, the two experimental samples were subjected to acid resistance test.

\subsection{Acid Resistance Test}

One of the problems in the construction industry over Portland cement is the chemical attack, which can either be in the form of acid or sulfate attack, as it causes deterioration which changes the behavior of the material. Sulfuric acid was chosen as the test media because it can attack the matrix by both acid and sulfate attack. Several studies have evaluated the acid resistance property using a 5\% (percentage by weight) sulfuric acid solution due to its aggressive condition $[19,30,31]$. Acid resistance is thus defined as the ability of the material to resist acid attack when exposed to such aggressive environment [32]. Hence, after curing for 28 days, the hardened soil geopolymer samples, SO-CFA-28 and SO-CFA-56, were immersed in a 5\% (percentage by weight) sulfuric acid solution for 28 days and 56 days, respectively $[19,25]$. The unconfined compressive strength (UCS) was measured after the immersion. To investigate the chemical stability of soil-fly ash geopolymer 
cement, the samples exposed in acidic condition for 28 days (SO-CFA-28) was further evaluated using XRD, FTIR, and SEM-EDX analysis.

\subsection{Leachability Test}

Leaching tests are used to assess the environmental characteristics and risks of a material, which can be applicable to soil-fly ash (SO-CFA) geopolymer cement. In this study, a modified column leaching test set-up (Figure 1) was employed in evaluating the leaching of metals such as $\mathrm{Na}, \mathrm{Si}, \mathrm{Al}, \mathrm{Ca}$, $\mathrm{Fe}, \mathrm{As}, \mathrm{Cr}, \mathrm{Pb}$, and $\mathrm{Cd}$ [33]. This type of leaching method requires continuous downflow of leachant in the solid material simulating the transport of aqueous media in the field. Soil geopolymer sample with the same mix proportion in Section 2.3 was prepared, molded in a PVC mold $(6.5 \mathrm{~cm}$ diameter $\times 13.0 \mathrm{~cm}$ height), and then cured for 28 days at ambient temperature. The mold containing soil geopolymer cement sample was then attached to a modified column leaching test set-up. The continuous flow of deionized water as leachant was supplied using a peristaltic pump with a speed of $0.3 \mathrm{rpm}$. Leachate was collected until it accumulates a volume equivalent to 5 pore volumes. One pore volume is considered as one leachate cycle. At the end of each cycle, the leachate was collected for metal analysis concentration using the Inductively Coupled Plasma Optical Emission Spectrometry (ICP-OES, Agilent 5100 ICP-OES, Agilent Technologies, Santa Clara, CA, USA). For this experiment, one pore volume was calculated to be equal to $172 \mathrm{~mL}$, which was collected for $10 \mathrm{~h}$. Pore volume was calculated using the equations below:

$$
\begin{aligned}
& \text { Total volume, } \quad V=\frac{\pi d^{2}}{4} \times h \\
& \text { Voids ratio, } \quad e=\frac{\gamma_{w} G_{s}}{\gamma_{d}}-1
\end{aligned}
$$

$$
\begin{gathered}
\text { Volume of solids, } \quad V_{s}=\frac{1}{1+e} \times V \\
\text { Volume of voids, } \quad V_{v}=V-V_{S} \text { (one pore volume) }
\end{gathered}
$$

where $\gamma_{d}$ is the dry density of SO-CFA geopolymer cement, $\gamma_{w}$ is the water density, $G_{s}$ is the specific gravity of soil-fly ash geopolymer cement, $d$ is the diameter of soil-fly ash geopolymer cement, and $h$ is the height of soil-fly ash geopolymer cement.

\subsection{X-ray Diffraction (XRD) Measurements}

The crystalline phase of both raw materials and geopolymer was determined using Multiflex Rigaku Automated Powder X-ray Diffractometer $(\mathrm{Cu} \mathrm{K} \alpha$ radiation; $\lambda=1.54 \AA$, Voltage $=40 \mathrm{kV}$, Current $=30.0 \mathrm{~mA}$ ). The sample was pulverized in an agate mortar until it reached a grain size of $\sim 10 \mu \mathrm{m}$. The powder sample was mounted on the XRD holder and was then subjected to a full scan analysis with a measuring angle of $5^{\circ}-60^{\circ}, 2 \theta$. The resolution for this analysis was set at 0.020 , with a scan speed maintained at $2^{\circ}$ per minute. Minerals were identified by Match Crystal Impact software version 3.4.2 (CRYSTAL IMPACT, Bonn, Germany), which uses the Inorganic Crystal Structure Database.

\subsection{Fourier Transform Infrared (FTIR) Spectroscopy Measurements}

FTIR spectroscopy technique was performed by the potassium $(\mathrm{KBr})$ method with Thermo Nicolet FT-IR Spectrometer 6700. For background measurements, the $\mathrm{KBr}$ powder was pressed into a thin circular film and was then analyzed using a transmittance mode range of $500-4000 \mathrm{~cm}^{-1}$. Powder sample (about $0.1-2 \% \mathrm{KBr}$ ) and $\mathrm{KBr}$ were then mixed and ground in an agate mortar. The mixture was pressed into thin and transparent pellet then placed into the instrument to evaluate the structural bonding properties of soil-fly ash geopolymer cement. 


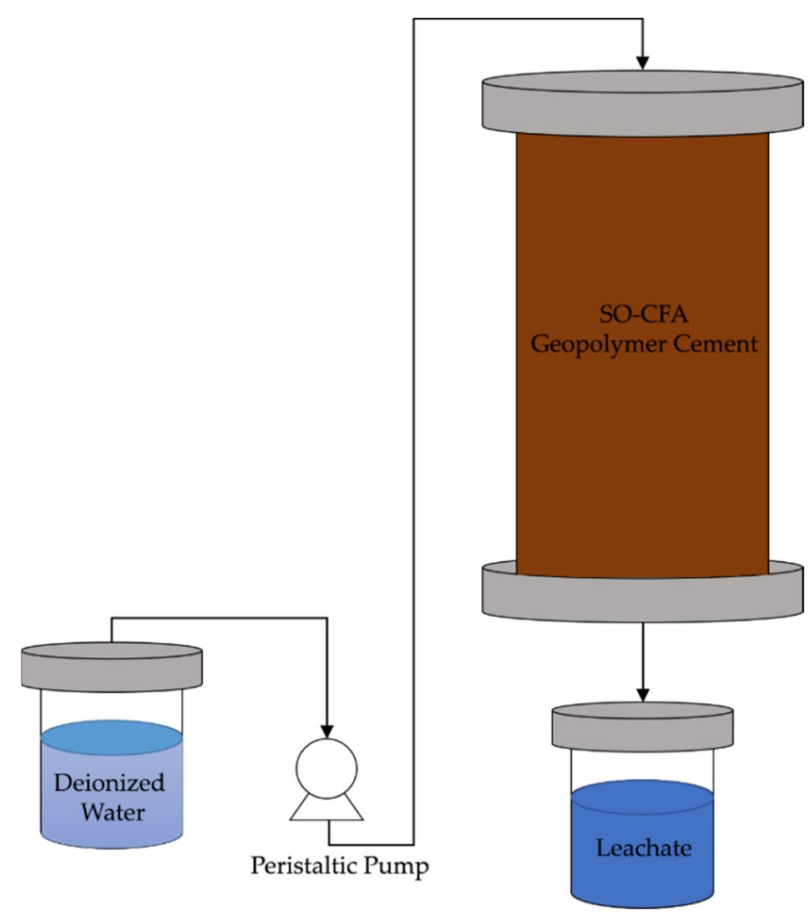

Figure 1. Schematic diagram of the modified column leaching test set-up.

\subsection{Scanning Electron Microscope-Energy-Dispersive X-ray (SEM-EDX) Spectroscopy Analysis}

SEM-EDX analysis were carried out using a field-emission scanning electron microscope (FESEM Dual Beam Helios Nanolab 600i, FEI, Hillsboro, OR, USA) with a voltage $=2.0 \mathrm{kV}$ and beam current $=43 \mathrm{pA}$ equipped with energy dispersive X-ray spectroscopy (EDS, FEI, Hillsboro, OR, USA) with a voltage of $15.0 \mathrm{kV}$ and beam current of $0.69 \mathrm{nA}$. The fractured samples were first stored in a desiccator with silica gel for $24 \mathrm{~h}$. The samples were then coated with a thin layer of gold using a sputter-coater to become conductive. The coated sample was mounted to the stub using conductive double-coated carbon tape and then placed in the instrument for analysis.

\section{Results and Discussion}

\subsection{Characterization of Raw Materials}

\subsubsection{Physical Properties}

Table 1 summarizes the physical properties of the soil (SO) and coal fly ash (CFA) used as raw materials. Soil used in this work is classified as brown silty sand (SM) in accordance with unified soil classification system. This indicates that the soil primarily composed of coarse-grained particles. In Figure 2, the grain size distribution of soil shows that more than $12 \%$ of its particles passed through sieve no. 200. By definition of Unified Soil Classification System (USCS), SM type of soil has characteristics of poorly graded sand-silt mixtures. Moreover, in terms of strength rating pertaining to value for foundations, it is rated as good to poor bearing value. When this type of soil becomes saturated, it may lead to additional construction problem. The non-plasticity result of the Atterberg limit of soil also shows that it is cohesionless, which means that the strength of the soil solely depends on the friction between the particles. This may be one of the reasons why pure soil cannot be molded. This is in agreement with the results of the study conducted in [34] where the same type of soil could not be molded for UCS testing. Hence, this kind of soil needs to be reinforced or stabilized for geotechnical engineering applications such as that of backfill. 
Table 1. Physical properties of raw materials.

\begin{tabular}{ccc}
\hline Property & Soil & Coal Fly Ash \\
\hline Specific Gravity & 2.54 & 2.85 \\
Liquid Limit & None & 12 \\
Plasticity Index & NP & 1 \\
Median Particle Size, $\mathrm{mm}$ & 0.70 & 0.00192 \\
\hline
\end{tabular}

On the other hand, the specific gravity values of soil and fly ash used in this study are 2.54 and 2.85 , respectively. A variation on the value of specific gravity depends on the composition of the material. The obtained values of specific gravity correlate with the grain size as shown in Figure 2, which clearly illustrates that fly ash has finer particles with a median diameter of $0.00192 \mathrm{~mm}$, as compared with the soil with a median diameter of $0.70 \mathrm{~mm}$. The gradation and Atterberg limit of fly ash show that it is predominantly composed of clayey fine-grained particles of low plasticity with a liquid limit value of 12 . The liquid limit and plasticity index characteristics explain the behavior of the material when it becomes saturated with water. A high value of liquid limit could mean more water is needed to saturate the mixture and a higher value of plasticity index could mean that the material consists of clayey particles. These parameters are relevant because these can affect the workability of the mixture [35].

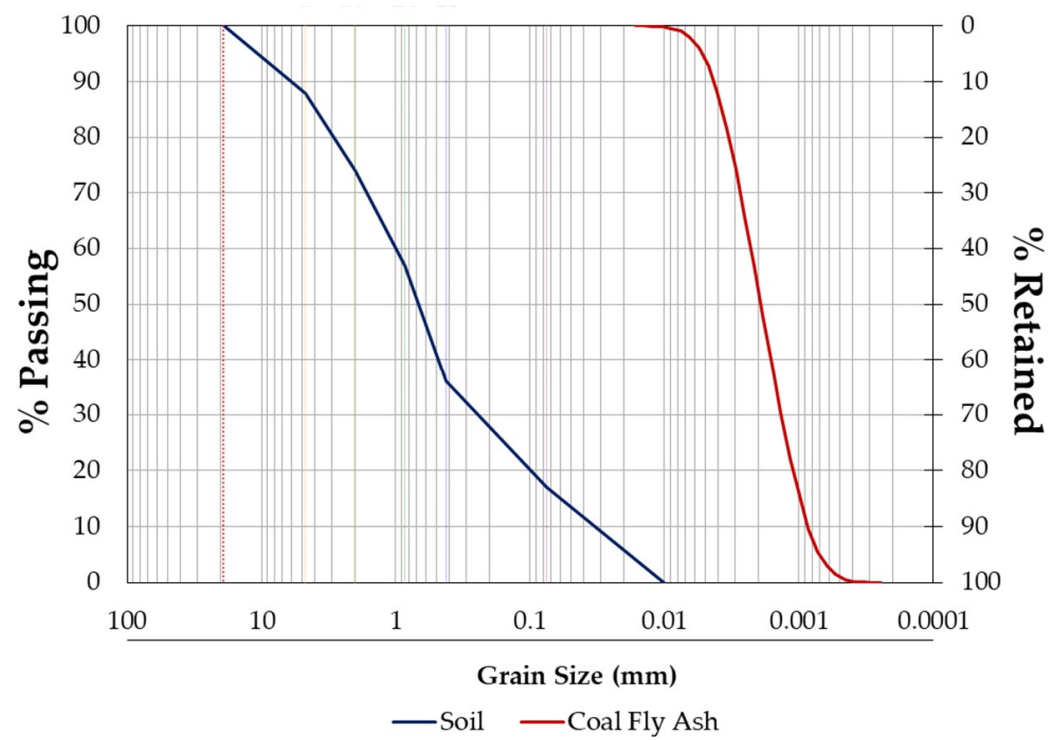

Figure 2. Particle size distribution of soil and coal fly ash [29].

\subsubsection{Chemical Properties}

Soil and coal fly ash are primarily composed of oxides of silicon $\left(\mathrm{SiO}_{2}\right)$, iron $\left(\mathrm{Fe}_{2} \mathrm{O}_{3}\right)$, aluminum $\left(\mathrm{Al}_{2} \mathrm{O}_{3}\right)$, and calcium $(\mathrm{CaO})$ as shown in Table 2. The coal fly ash is classified as ASTM class F fly ash or low-calcium fly ash with a total $\mathrm{SiO}_{2}, \mathrm{Al}_{2} \mathrm{O}_{3}$, and $\mathrm{Fe}_{2} \mathrm{O}_{3}$ of $77.83 \%$ (i.e., more than $70 \%$ of the total weight according to ASTM C 616-03). The presence of alumina and silica compounds in coal fly ash is an indication that it can be used as geopolymer precursor.

The presence of $\mathrm{Si}$ and $\mathrm{Al}$ structural bond of soil and coal fly ash were also confirmed using FTIR analysis as presented in Figure 3. The presence of aluminosilica functional group was demonstrated on wavenumber range $900-1100 \mathrm{~cm}^{-1}$. The anti-symmetric Si-O-T stretching vibrations (T represents either Si or Al) of soil and coal fly ash were illustrated at a wavenumber of 1032 and $912 \mathrm{~cm}^{-1}$, and 1099 and $1020 \mathrm{~cm}^{-1}$, respectively [36]. Moreover, spectral peak in the range of $538-779 \mathrm{~cm}^{-1}$ is the bending vibration mode of $\mathrm{Si}-\mathrm{O}-\mathrm{T}$ bonds. The presence of peaks at $3423-3620 \mathrm{~cm}^{-1}$ and $1637-1649 \mathrm{~cm}^{-1}$ are assigned to the $\mathrm{O}-\mathrm{H}$ stretching vibration, which is indicative of moisture in the raw materials [11]. 
Table 2. Chemical composition of soil and fly ash.

\begin{tabular}{ccc}
\hline Oxide & Soil (Mass \%) & Coal Fly Ash (Mass \%) \\
\hline $\mathrm{SiO}_{2}$ & 38.87 & 24.65 \\
$\mathrm{Fe}_{2} \mathrm{O}_{3}$ & 34.06 & 44.63 \\
$\mathrm{Al}_{2} \mathrm{O}_{3}$ & 12.53 & 8.55 \\
$\mathrm{CaO}$ & 6.82 & 16.04 \\
$\mathrm{TiO}_{2}$ & 3.09 & 1.32 \\
$\mathrm{~K}_{2} \mathrm{O}$ & 1.87 & 1.18 \\
$\mathrm{SO}_{3}$ & - & 1.63 \\
Others & 2.76 & 2.00 \\
\hline
\end{tabular}
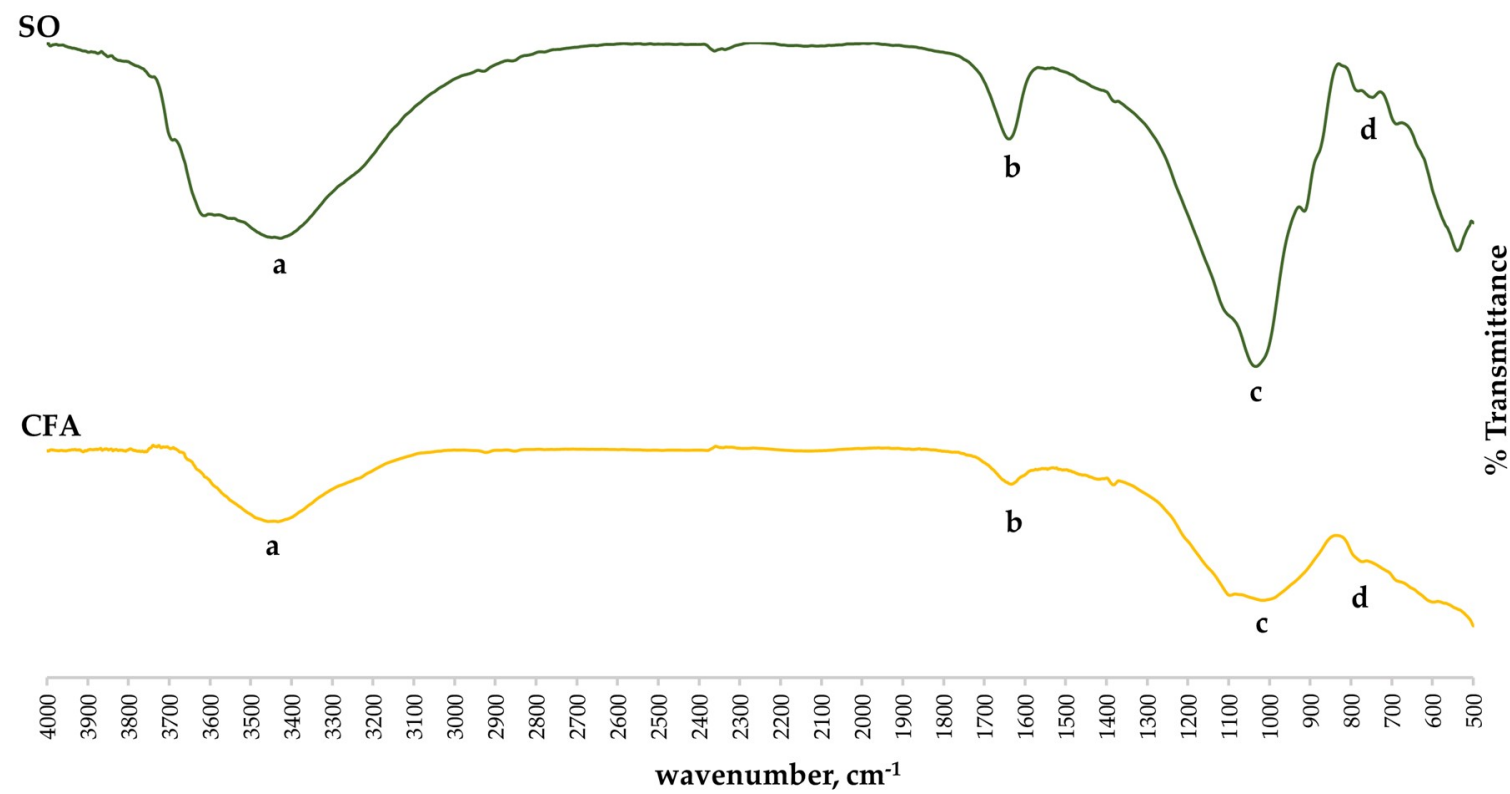

Figure 3. FTIR spectrum of soil (SO) and coal fly ash (CFA) (a: $\mathrm{O}-\mathrm{H}$ stretching vibration; b: $\mathrm{O}-\mathrm{H}$ antisymmetric stretching; c: Si-O-T antisymmetric stretching ( $\mathrm{T}$ is either $\mathrm{Si}$ or $\mathrm{Al}$ ) and; d: Si-OT bending vibration).

The mineralogical phase of soil as shown in the XRD pattern of Figure 4 contains quartz $\left(\mathrm{SiO}_{2}\right)$ and magnetite $\left(\mathrm{Fe}_{3} \mathrm{O}_{4}\right)$. The presence of these minerals can be correlated with the result of XRF analysis of soil composed of oxides of silica and iron. Another crystalline present in soil is montmorillonite $\left.\left((\mathrm{Na}, \mathrm{Ca})_{0.3}(\mathrm{Al}, \mathrm{Mg})_{2} \mathrm{Si}_{4} \mathrm{O}_{10}(\mathrm{OH})_{2} \cdot \mathrm{nH}_{2} \mathrm{O}\right)\right)$. A hump background between $20^{\circ}$ and $40^{\circ} 2 \theta$ of soil may correspond to the amorphous content of material [11,37]. Additionally, the XRD pattern of coal fly ash reveals the presence of quartz $\left(\mathrm{SiO}_{2}\right)$, hematite $\left(\mathrm{Fe}_{2} \mathrm{O}_{3}\right)$, and magnetite $\left(\mathrm{Fe}_{3} \mathrm{O}_{4}\right)$. These minerals can be associated with the abundance of silica and iron compounds, which can be correlated with the result of elemental analysis of coal fly ash. The notable broad peaks between $29^{\circ}$ and $44^{\circ} 2 \theta$ of CFA, as depicted in Figure 4, may indicate that a substantial fraction of coal fly ash is amorphous. It is believed that the amorphous content of the material has played a major role in geopolymerization due to its reactive nature. This can be correlated with the study conducted in [17], wherein materials having a high amorphous content were found to yield geopolymer with better mechanical properties in binders [38]. The presence of minerals is in agreement with the result of XRF analysis and IR analysis as demonstrated in Table 2 and Figure 3. Moreover, the presence of iron in XRF analysis has also been depicted in the XRD pattern with the presence of hematite $\left(\mathrm{Fe}_{2} \mathrm{O}_{3}\right)$ and magnetite $\left(\mathrm{Fe}_{3} \mathrm{O}_{4}\right)$. 


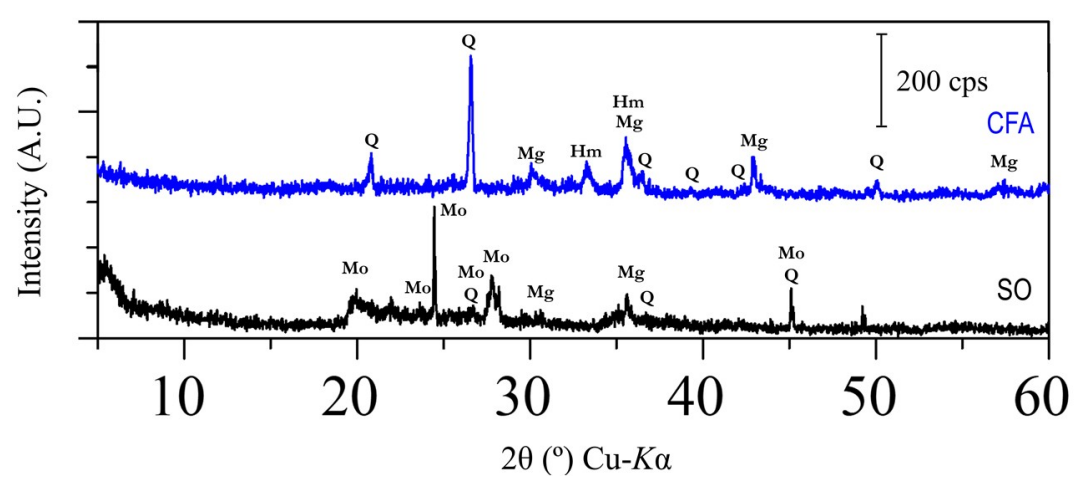

Figure 4. XRD pattern of soil (SO) and coal fly ash (CFA) (Mo-Montmorillonite; Q-Quartz; $\mathrm{Mg}$-Magnetite; Hm-Hematite).

\subsection{Acid Resistance Behavior}

\subsubsection{Unconfined Compressive Strength}

The control sample soil-fly ash (SO-CFA) geopolymer, not immersed in acidic condition, was tested after the 28-day curing has a recorded unconfined compressive strength of 1.0 MPa. Note that such strength development of the stabilized soil even at ambient curing suggests geopolymerization has occurred. Geopolymeric gels that are formed in the soil can assist the soil particles to form more compact microstructures [18]. The soil used in this study is nonplastic and cannot be molded to exhibit measurable unconfined compressive strength; however, when mixed as part of one-part geopolymer binder system, it has strength that can be used as backfill/foundation. With the standard stated in the National Structural Code of the Philippines, stabilized soil with an unconfined compressive strength of at least $0.075 \mathrm{MPa}(75 \mathrm{kPa})$ for the SM type soil can be recommended for backfill/foundation applications [39].

Moreover, our study indicates that strength development of soil-fly ash (SO-CFA) geopolymer still progressing even if the specimen is immersed in $5 \%$ (percentage by weight) sulfuric acid solution. The measured unconfined compressive strength of soil-fly ash geopolymer cement immersed in acidic condition for 28 and 56 days were 2.6 and $3.2 \mathrm{MPa}$, respectively. The results of the compressive strength show that the matrix of soil-fly ash geopolymer cement seemed not to be affected by the presence of an acid. Likewise, the strength of soil-fly ash geopolymer immersed in acidic condition has also been found to increase as the length of immersion increases.

As for the product designed for fit to purpose, the soil-fly ash geopolymer developed in this study has an unconfined compressive strength comparable to soil stabilized with lime and/or cement despite its exposure to a more aggressive environment as shown in Table 3. Based on several studies, soil treated with lime has a range of unconfined compressive strength value of 0.01-3.0 MPa. Conversely, soil stabilized with cement can have unconfined compressive strength values ranging from 0.10 to $0.90 \mathrm{MPa}$.

The increase in unconfined compressive strength of this study during the sulfuric acid immersion was not in agreement with the result of the study conducted in [25], wherein a loss in strength was recorded. The mechanism that may occur during sulfuric acid immersion involves an attack of acid on aluminosilicate bonding present in the geopolymer matrix. This behavior may result in deterioration of the geopolymeric network, particularly attacking the aluminosilicate bonding, which could result in an increase in the formation of $\mathrm{Si}-\mathrm{OH}$ and $\mathrm{Al}-\mathrm{OH}$, and thereby a loss in compressive strength. However, the strength loss was not observed in this study. In fact, an increase in strength was manifested. This may be attributed to the type of gel matrix formed and may be closely related to the intact geopolymer network structure of the $\mathrm{Si}-\mathrm{O}$ and $\mathrm{Al}-\mathrm{O}$ in the matrix, which makes the soil-fly ash geopolymer cement in this study an acid resistant. Similar findings were observed in [19], in which the 
geopolymer was a better acid resistant due to the intact matrix of the geopolymeric network and to the possible neutralization of Na-rich gel with acidic media.

Table 3. Unconfined compressive strength between lime/cement stabilized soil and soil-fly ash geopolymer cement.

\begin{tabular}{cccc}
\hline Mixture & Condition Prior UCS Testing & $\begin{array}{c}\text { Unconfined Compressive } \\
\text { Strength (UCS)/MPa }\end{array}$ & References \\
\hline Geopolymer (FA + & 28 days curing + Immersion in & $1.0-3.2$ & This study \\
Alkali Activator) & acid solution for 28, and 56 days & $0.50-0.90$ & {$[40]$} \\
Cement & $7,28,90$ days curing & 0.07 & {$[34]$} \\
Waste Limestones & 28 days curing & $0.10-0.70$ & {$[41]$} \\
Lime-Cement & 30 days curing & $0.01-0.08$ & {$[42]$} \\
Lime & $7,15,30,45$ days curing & $0.10-0.24$ & {$[43]$} \\
Cement & 7 days curing & $0.40-2.40$ & {$[44]$} \\
Lime & 7,90 days curing & $0.25-3.00$ & {$[45]$} \\
Lime & $3,7,21,28$ days curing & & \\
\hline
\end{tabular}

\subsubsection{Structural Bonding Property}

The structural bonding of the control soil-fly ash geopolymer cement (SO-CFA) and acid-immersed soil-fly ash geopolymer cement (SO-CFA-28) were investigated using FTIR analysis as presented in Figure 5. Table 4 shows the values of the observed peak of raw materials, SO-CFA, and SO-CFA-28. The O-H antisymmetric was observed at $1637-1643 \mathrm{~cm}^{-1}$ [46]. Main structural bonds are located at peaks between 900 and $1099 \mathrm{~cm}^{-1}$ which indicates Si-O-T (T, either Al or Si) anti-asymmetric stretching [36].

Table 4. Spectral peaks assignment.

\begin{tabular}{ccccc}
\hline Assignment of Spectral Peaks & SO & CFA & SO-CFA & SO-CFA-28 \\
\hline O-H anti-symmetric stretching & 1643 & 1639 & 1639 & 1637 \\
Si-O-T anti-symmetric stretching & 912,1032 & 1099,1020 & 1018 & 1032 \\
Si-O-T bending vibration & $748,685,538$ & 773,602 & 692,542 & $779,692,536$ \\
\hline
\end{tabular}

As shown in Figure 5, the narrowing of peaks was observed between the spectra of raw materials and soil-fly ash (SO-CFA) geopolymer cement. This may be due to the further stretching of the Si-O-T bonds. It was also observed that a shift in peaks occurred on the main bands of SO, CFA, and SO-CFA samples toward a decreasing wavenumber, from 1099 to $1018 \mathrm{~cm}^{-1}$. The shift of this band is indicative of the geopolymerization in the solid matrix [47,48]. Additionally, peaks within the main band for SO-CFA-28 were clearly sharper than those of the SO-CFA sample. This is an indication of a change in the structural matrix of geopolymer brought by either the attack of the acid or the further development of the geopolymer matrix. A shift in peaks to increasing wavenumbers, from 1018 to $1032 \mathrm{~cm}^{-1}$, of the SO-CFA and SO-CFA-28 samples may indicate partial depolymerization of the amorphous gel matrix due to acid attack, thereby dissolving some of the amorphous content of the gel matrix [48]. Similar findings were reported in [14], wherein the shift in peaks was caused by the depolymerization due to acid attack. Partial dissolution of the gel matrix could result in a compressive loss of the geopolymer. However, with the increasing unconfined compressive strength as reported in Section 3.2.1, this mechanism is not evident with the SO-CFA-28 sample. This partial depolymerization that may have occurred still has not caused significant impact to affect the unconfined compressive strength of soil-fly ash geopolymer cement developed in this study. This observation can be correlated with the hypothesis on the possible intact network that had been formed on the SO-CFA-28 sample, making it an acid-resistance material [19]. 


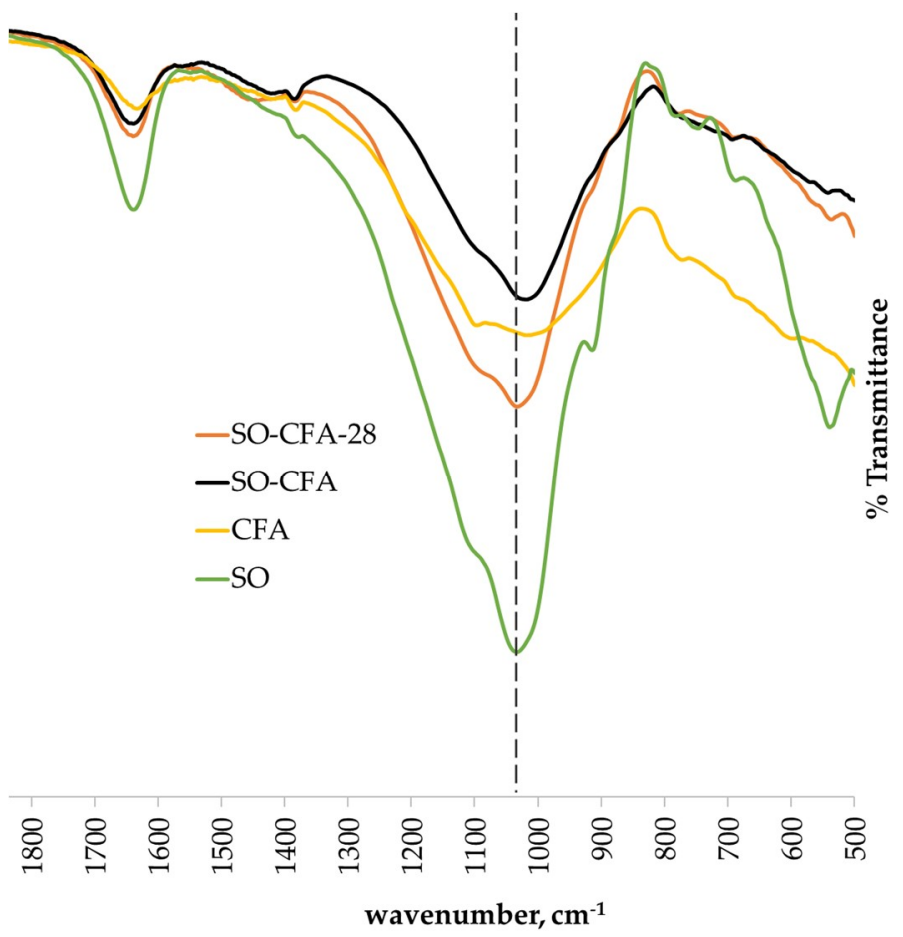

Figure 5. FTIR comparative analysis of raw materials and soil-fly ash geopolymer cement.

\subsubsection{Mineralogical Phase}

The difference in mineralogical phase between soil, coal fly ash, SO-CFA, and SO-CFA-28 has been demonstrated in Figure 6. The presence of minerals such as quartz $\left(\mathrm{SiO}_{2}\right)$, hematite $\left(\mathrm{Fe}_{2} \mathrm{O}_{3}\right)$, and magnetite $\left(\mathrm{Fe}_{3} \mathrm{O}_{4}\right)$ are expected given that the soil and coal fly ash contain oxides of silica and iron.

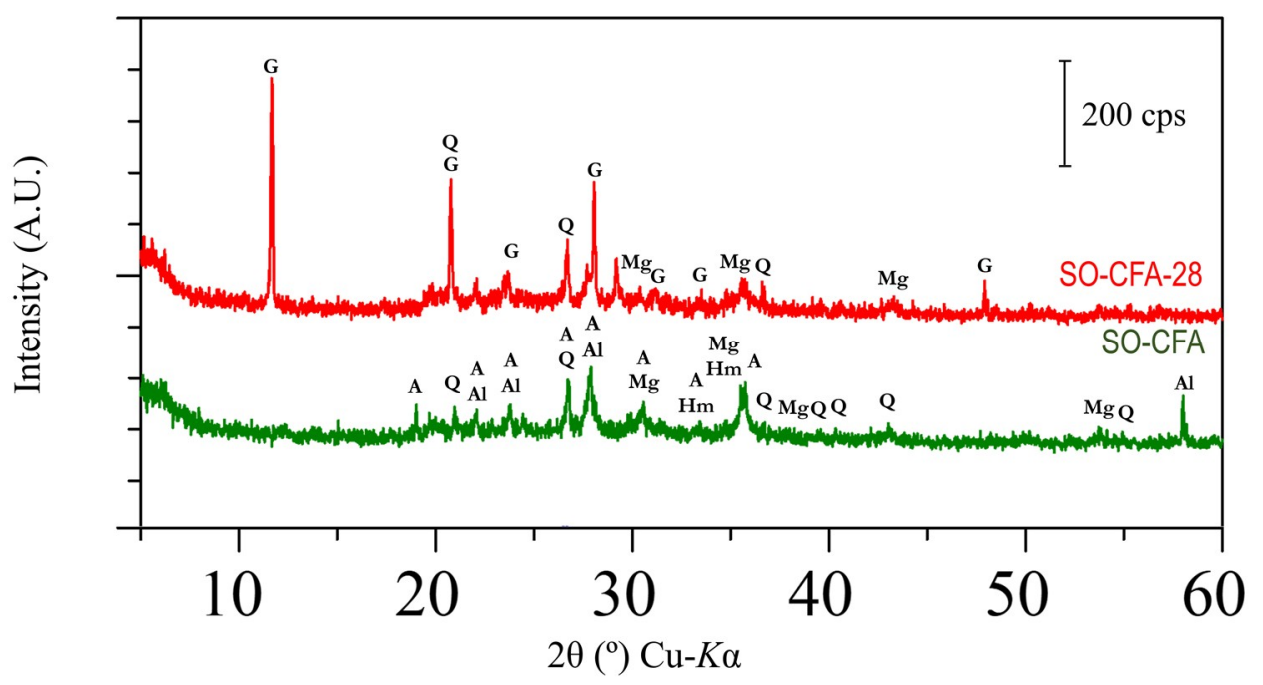

Figure 6. XRD comparative analysis of SO-CFA and SO-CFA-28 (Q-Quartz; Hm-Hematite; $\mathrm{Mg}$-Magnetite; G-Gypsum; A-Anorthite; Al-Albite).

The disappearance of some peaks between the raw material and the soil-geopolymer cement (SO-CFA and SO-CFA-28) is worth noting. The disappearance of peaks, as for the case of montmorillonite $\left((\mathrm{Na}, \mathrm{Ca})_{0.3}(\mathrm{Al}, \mathrm{Mg})_{2} \mathrm{Si}_{4} \mathrm{O}_{10}(\mathrm{OH})_{2} \cdot \mathrm{nH}_{2} \mathrm{O}\right)$ and hematite $\left(\mathrm{Fe}_{2} \mathrm{O}_{3}\right)$, may be associated with the concealing of amorphous phase over the crystalline phase. This may also imply that crystalline components, for instance, quartz and magnetite initially present in the precursor, have not participated 
in geopolymerization [47]. Interestingly, geopolymerization using soil, CFA, and solid alkali activators has led to the formation of new crystal-anorthite $\left(\mathrm{CaAl}_{2} \mathrm{Si}_{2} \mathrm{O}_{8}\right)$ and albite $\left(\mathrm{NaAlSi}_{3} \mathrm{O}_{8}\right)$ as shown in the SO-CFA pattern. This is an indication that the components such as $\mathrm{SiO}_{2}$ and $\mathrm{Al}_{2} \mathrm{O}_{3}$ present in raw materials and alkali activators have reacted. Given the acidic media contains sulfate ions, the presence of gypsum $\left(\mathrm{CaSO}_{4} \cdot 2 \mathrm{H}_{2} \mathrm{O}\right)$ in $\mathrm{SO}-\mathrm{CFA}-28$ is expected.

After further exposure to the acidic environment, the mineralogical phase of soil-fly ash geopolymer cement (SO-CFA-28) was examined. The disappearance of albite and anorthite peaks have been observed and may be explained similarly to the mechanism behind weathering. The disappearance of albite peaks may be associated with its dissolution in acidic media. This results in the exchange of hydrogen ions for sodium ions at the surface of the albite, breaking $\mathrm{Al}-\mathrm{O}$ bonds and forming an Si-rich precursor, and the hydrolysis of $\mathrm{Si}-\mathrm{O}$ bonds [49]. On the other hand, anorthite weathering requires only the breaking of the $\mathrm{Al}-\mathrm{O}$ bonds [50]. The framework of the anorthite with an $\mathrm{Si} / \mathrm{Al}$ ratio of 1, upon exposure to acidic media, may deteriorate due to the attack of the hydrogen ions. This deterioration may result in the detachment of calcium and aluminum, thereby leaving tetrahedra of silica [50]. The presence of available calcium ions, which resulted from the dissolution of anorthite and sulfate ions from acidic media, leads to the formation of a new crystal, with peaks of gypsum $\left(\mathrm{CaSO}_{4} \cdot 2 \mathrm{H}_{2} \mathrm{O}\right)$ at $11.60^{\circ}$ and $20.70^{\circ} 2 \theta$, in the SO-CFA-28 sample [19]. This finding is similar to that found in [19], in which the formation of a new crystal such as gypsum was observed after immersion in a sulfuric acid solution.

Exposure of anorthite in the acidic environment could result in (i) the dissolution of a framework resulting in amorphous polymer and (ii) the further formation of $\mathrm{N}-\mathrm{A}-\mathrm{S}-\mathrm{H}$ and $\mathrm{C}(-\mathrm{A})-\mathrm{S}-\mathrm{H}$ gel. The increase in unconfined compressive strength upon exposure in the acidic environment may be explained by the idea that the crystalline geopolymer was more stable than amorphous geopolymer when exposed to an acidic environment [32]. In this case, the dissolution of anorthite may have caused an increase in strength. Similar findings were observed in [51]. The results of that study showed a disappearance and formation of new peaks in XRD analysis. Notable findings such as an increase in strength of geopolymer binders over time and a decrease in strength of a cement-based binder under acidic media were also observed. The N-A-S-H gel phase present in geopolymer binder is believed to neutralize the acid, thereby preventing the matrix from further deterioration [19].

In the case of cement-based binder, deterioration is attributed to the attack of an acid on the calcium hydroxide in the cement paste and on the $\mathrm{C}-\mathrm{S}-\mathrm{H}$ framework, which could lead to the formation of more gypsum in the matrix. The presence of gypsum in the matrix can be detrimental because of its solubility in water [52]. This could affect the long-term durability, as the presence of this mineral can cause expansions and cracks. This may explain the advantage of a matrix with a N-A-S-H/C $(-\mathrm{A})-\mathrm{S}-\mathrm{H}$ gel over one with a C-S-H gel that is typically found in ordinary Portland cement-based binder systems. This also supports our hypothesis that an intact geopolymeric network has been developed in this study, which results in an increase in compressive strength despite the presence of gypsum. The result of the XRD pattern is also in agreement with the result of FTIR analysis, wherein a change in structure was evident with the shift of peaks, which corresponds to the formation of new crystals/component in the soil-geopolymer cement matrix.

\subsubsection{Surface Morphology}

Morphological characteristics of soil-fly ash geopolymer cement without immersion (SO-CFA sample) and with immersion in $5 \%$ by weight sulfuric acid for 28 days (SO-CFA-28 sample) were carried out using SEM-EDX analysis. The SEM images (Figure 7a,b) of the SO-CFA samples clearly contain a number of spherical particles similar to the morphology of coal fly ash. The spherical particles that cause large voids and pores in the matrix may be attributed to the unreacted coal fly ash (Figure 7c-e). Partial polymerization of CFA particles has also been observed as shown in Figure 7f. Furthermore, the presence of needle-like structures was observed in Figure 7e, which also indicates partially dissolved coal fly ash in the sample [53]. Additionally, the magnification of SO-CFA SEM images reveals that some of the spherical particles are covered with a corrugated surface (Figure 8a) [54]. 
As confirmed by EDX analyses presented in Figure 8b, spikes of iron and oxygen have been noted. These resemble the morphology of hematite $\left(\mathrm{Fe}_{2} \mathrm{O}_{3}\right)$ and magnetite $\left(\mathrm{Fe}_{3} \mathrm{O}_{4}\right)$ [55]. This is consistent with the result of the XRD pattern of the SO-CFA sample in Section 3.2.3.

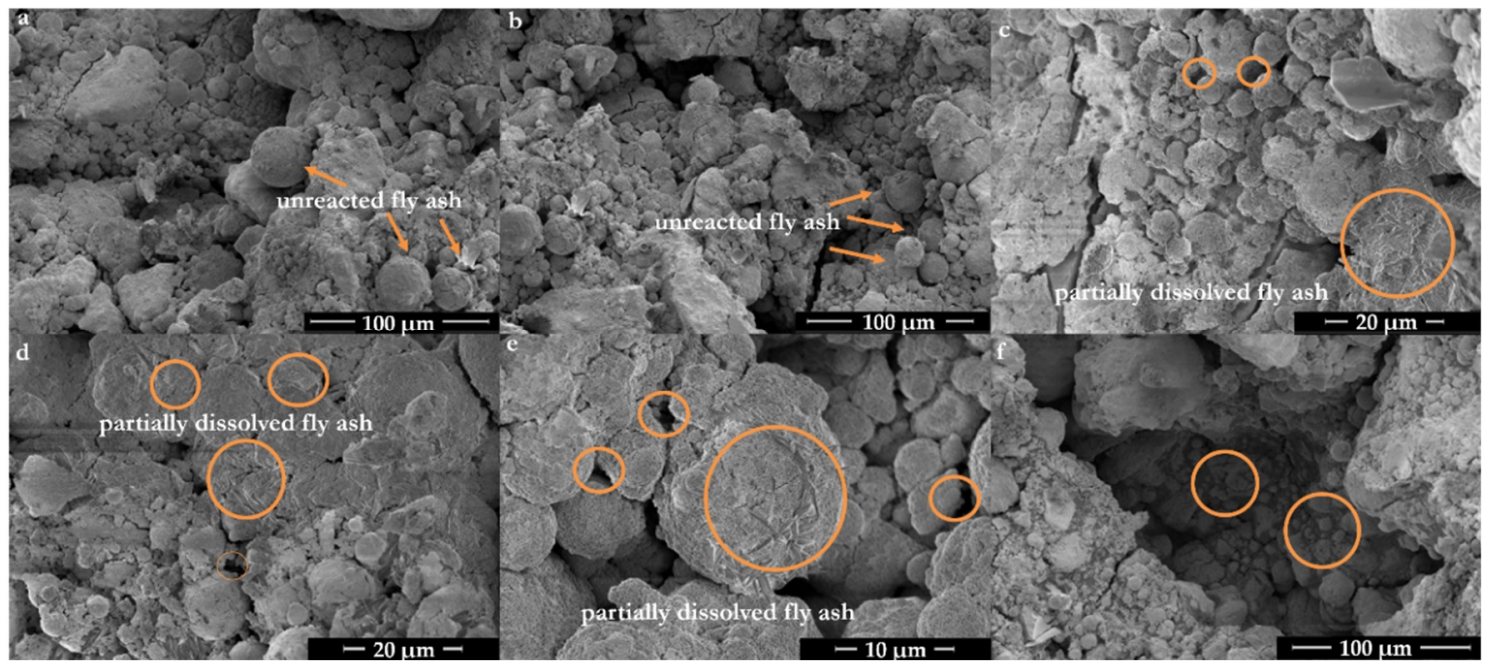

Figure 7. SEM images of SO-CFA sample. (a) unreacted fly ash at 750× magnification; (b) unreacted fly ash at $700 \times$ magnification; $(\mathbf{c}, \mathbf{d})$ partially dissolved fly ash at $2500 \times$ magnification; (e) presence of voids and needle-like structures at 5000 $\times$ magnification; (f) partial polymerization at $750 \times$ magnification.
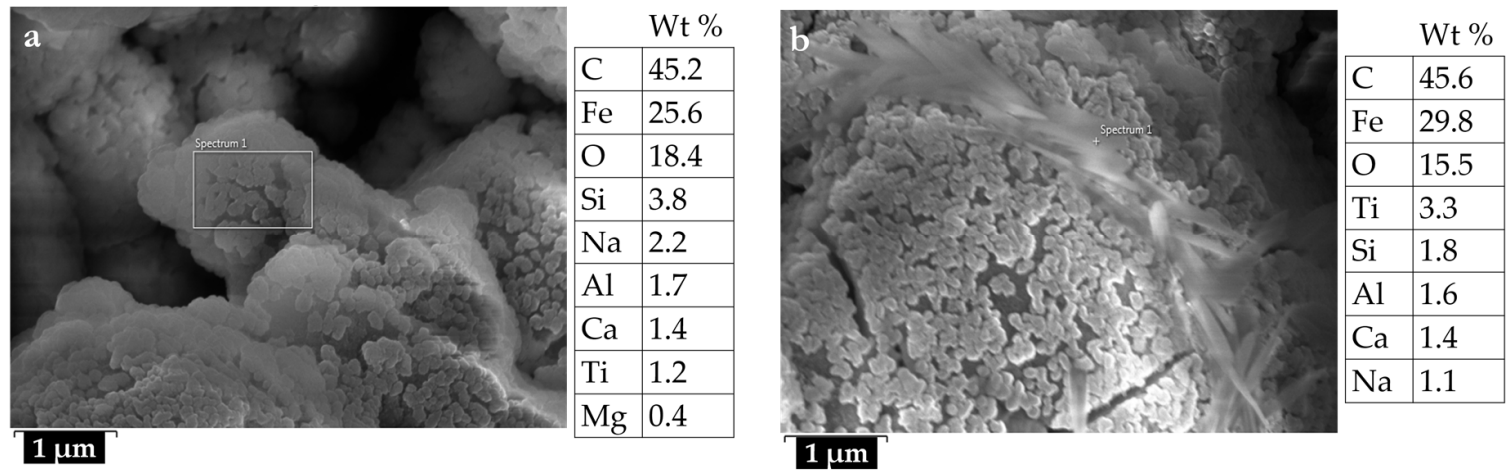

Figure 8. EDX analysis on the region of interest for (a) magnetite and (b) hematite in the SO-CFA sample.

On the other hand, SO-CFA-28 has a homogeneous phase structure as evidently illustrated in Figure 9a-d, relative to the SO-CFA sample. It also contains a lesser amount of unreacted coal fly ash. The smaller voids and pores on the morphology led to a well compacted and cemented surface. A rod-like structure from a broken sphere was also observed (Figure 9e). Based on the EDX analysis, this morphology has a high iron content. Another study [56] showed similar characteristics in which such a surface was described as having a prismatic needle feature. This may indicate the partial dissolution of coal fly ash, resulting in the exposure of smaller particles.

Moreover, hexagonal shape structures were also evident in the sample (Figure 9f). As confirmed by EDX analysis (Figure 10), these structures are rich in calcium and sulfur. This resembles gypsum $\left(\mathrm{CaSO}_{4} \cdot 2 \mathrm{H}_{2} \mathrm{O}\right)$. Formation of gypsum may be explained by the mechanism behind the sulfate attack in the matrix. This involves the reaction of sulfate ions from acidic media with the free calcium present in the geopolymeric gel. Evidence of gypsum formation was also revealed in the XRD patterns of SO-CFA-28 (Figure 6). 


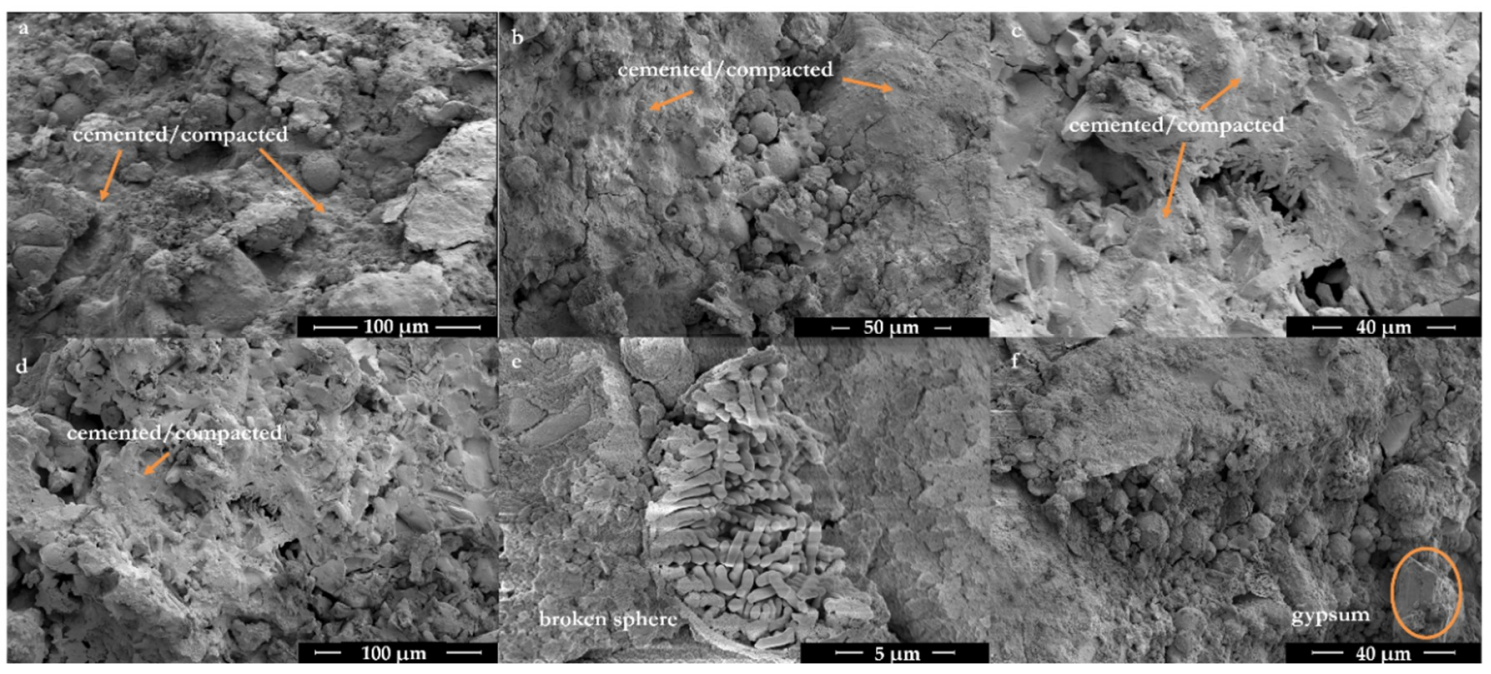

Figure 9. SEM image of SO-CFA-28 sample. Cemented and compacted structure at various magnifications (a) $700 \times$ magnification, (b) $1000 \times$ magnification, (c) 1500 $\times$ magnification, (d) $700 \times$ magnification; (e) rod-like structure at 10,000 $\times$ magnification; (f) presence of gypsum at $1500 \times$ magnification.

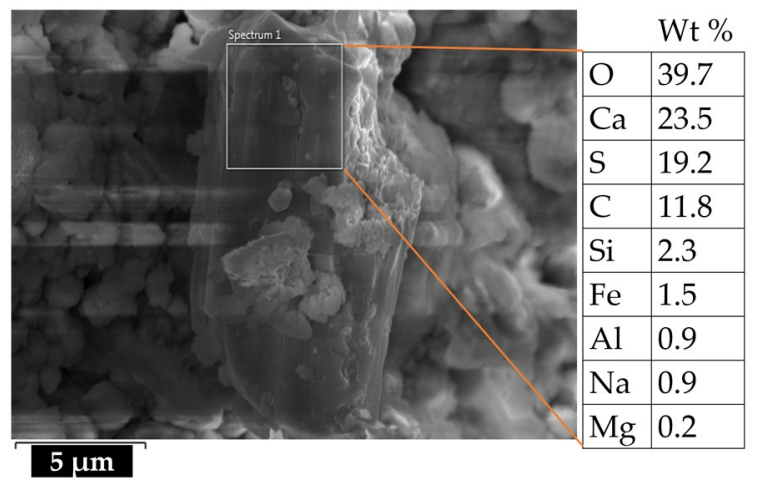

Figure 10. EDX analysis on the rectangular region of interest suspected of gypsum formation on SO-CFA-28 sample.

Based on the EDX results, SO-CFA and SO-CFA-28 samples were composed of $\mathrm{Si}, \mathrm{Al}, \mathrm{Na}, \mathrm{Ca}, \mathrm{Fe}, \mathrm{O}$, and $\mathrm{C}$. Geopolymeric gel microstructures were investigated by calculating the following molar ratios based on elemental composition: $\mathrm{Si} / \mathrm{Al}, \mathrm{Na} / \mathrm{Al}, \mathrm{Na} / \mathrm{Si}, \mathrm{Ca} / \mathrm{Si}$, and $\mathrm{Fe} / \mathrm{Si}$. Results are summarized in Table 5 .

Table 5. Summary of molar ratios based on the result of EDX analysis of gel formation.

\begin{tabular}{cccccc}
\hline Sample & $\mathbf{S i} / \mathbf{A l}$ & $\mathbf{N a} / \mathbf{A l}$ & $\mathbf{N a} / \mathbf{S i}$ & $\mathbf{C a} / \mathbf{S i}$ & $\mathbf{F e} / \mathbf{S i}$ \\
\hline SO-CFA & $3.91 \pm 1.86$ & $1.62 \pm 0.50$ & $0.50 \pm 0.25$ & $0.17 \pm 0.12$ & $1.04 \pm 1.36$ \\
SO-CFA-28 & $2.61 \pm 0.68$ & $1.00 \pm 0.40$ & $0.38 \pm 0.11$ & $0.55 \pm 1.04$ & $0.31 \pm 0.15$ \\
\hline
\end{tabular}

Based on the calculated molar ratios, SO-CFA dominantly composed Na-rich gels, while SO-CFA-28 sample comprises of gels with $\mathrm{Na}$ and $\mathrm{Ca}$. The coexistence of these gel matrices, which are believed to be sodium aluminosilicate hydrate (N-A-S-H) and calcium (alumino) silicate hydrate $(\mathrm{C}(-\mathrm{A})-\mathrm{S}-\mathrm{H})$ can cause significant improvement in the compressive strength [57]. This is consistent with the result of the unconfined compressive strength as presented in Section 3.2.1, in which the UCS of SO-CFA-28 significantly increased.

The coexistence of these gel matrices has also been observed in [58]. The results showed that the amount of available calcium ions present in the sample has a significant effect on the formation of 
the gel matrix. Projection of gel chemistry showed that a lower content of calcium in the proportion mix could produce a N-A-S-H gel. Similar findings were observed in [59], wherein the formation of $\mathrm{N}-\mathrm{A}-\mathrm{S}-\mathrm{H}$ gel demonstrates that some sodium replaces calcium in the $\mathrm{C}-\mathrm{S}-\mathrm{H}$ matrix. On the other hand, a higher content of calcium could produce a chain silicate of $\mathrm{C}(-\mathrm{A})-\mathrm{S}-\mathrm{H}$ gel. This can be correlated with the XRD pattern of SO-CFA-28 in which there was a potential increase in available calcium ions due to the disappearance of anorthite peaks. An increase in calcium ions could favor the development of $\mathrm{C}(-\mathrm{A})-\mathrm{S}-\mathrm{H}$ and hence an increase in $\mathrm{Ca} / \mathrm{Si}$ molar ratios. This gel formation mechanism may also explain the coexistence of both gels probably present in the SO-CFA-28 sample.

The high amount of iron present in the matrix is also worth noting. It is believed that the iron component participates in geopolymerization [56]. This can be correlated with the result of XRD analysis of raw materials and geopolymer, as presented in Figure 6. Peak intensities of iron-rich crystals almost disappeared after further geopolymerization. Given the molar ratios summarized in Table 5, these gel compositions resemble a typical poly(ferro-sialate-siloxo) and poly(ferro-sialate-disiloxo) type of binder with a formula relatively close to $[\mathrm{Ca}, \mathrm{Na}]-[-\mathrm{Fe}-\mathrm{O}-]_{\mathrm{x}}-[\mathrm{Si}-\mathrm{O}-\mathrm{Al}-\mathrm{O}-]_{1-\mathrm{x}}-[-\mathrm{Si}-\mathrm{O}-]_{\mathrm{y}}$ with $\mathrm{x}$ values less than or equal to 0.5 and $\mathrm{y}$ values between 0 and 25 [60].

\subsection{Leachability Behavior}

Table 6 shows the concentration of different metals leached from the control soil-fly ash geopolymer cement using ICP OES after 10, 20, 30, 40, and $50 \mathrm{~h}$ of cycle time. A considerable amount of $\mathrm{Al}, \mathrm{Ca}, \mathrm{Fe}, \mathrm{Na}$, and $\mathrm{Si}$ exhibits high leachability. A trace amount of heavy metals such as $\mathrm{As}, \mathrm{Cd}, \mathrm{Cr}$, and $\mathrm{Pb}$ has been observed. A high concentration of $\mathrm{Al}, \mathrm{Na}$, and $\mathrm{Si}$ is attributed to the high initial content of $\mathrm{Al}, \mathrm{Na}$, and $\mathrm{Si}$ in the raw material and alkali activator. A minimal amount of Fe has been leached out, from $12.54 \mathrm{ppm}$ in the 1 st cycle to $0.94 \mathrm{ppm}$ in the 5th cycle, despite its high content in soil and coal fly ash. The lower solubility may be attributed to the incorporation of the Fe in the geopolymer matrix. This is consistent with the result of microstructure analysis as presented in Section 3.2.4, wherein the gel matrix is predominantly a typical poly(ferro-sialate-siloxo) or poly(ferro-sialate-disiloxo) binder. Additionally, Ca leaching may support the presence of gypsum in the geopolymer matrix in SO-CFA-28. This is evidence that the free calcium compounds may have reacted with the sulfuric acid solution, thereby forming gypsum. The leached out Ca may come from the unreacted $\mathrm{Ca}$ in the matrix due to the insufficient amount of reactive silica and alumina available for gel formation. The minimal amount of percentage leached of $\mathrm{Ca}$ after 5 cycles may have been due to its incorporation as part of the anorthite $\left(\mathrm{CaAl}_{2} \mathrm{Si}_{2} \mathrm{O}_{8}\right)$ framework.

Table 6. Concentration (ppm) of leached metals.

\begin{tabular}{ccccccccccc}
\hline Cycle & Contact Time (h) & $\mathbf{A l}$ & $\mathbf{C a}$ & $\mathbf{F e}$ & $\mathbf{N a}$ & $\mathbf{S i}$ & $\mathbf{A s}$ & $\mathbf{C d}$ & $\mathbf{C r}$ & $\mathbf{P b}$ \\
\hline 1st & 10 & 119.765 & 6.76 & 12.54 & 18720.57 & 17.98 & 12.09 & 0.001 & 1.21 & 0.92 \\
2nd & 20 & 37.936 & 2.57 & 3.68 & 7624.63 & 67.27 & 2.78 & 0.001 & 0.30 & 0.45 \\
3rd & 30 & 27.707 & 2.67 & 2.18 & 5114.85 & 54.56 & 1.36 & 0.001 & 0.18 & 0.69 \\
4th & 40 & 15.51 & 1.78 & 0.87 & 3899.48 & 10.06 & 0.92 & 0.185 & 0.14 & 2.00 \\
5th & 50 & 16.28 & 1.76 & 0.94 & 3145.73 & 15.17 & 0.66 & 0.057 & 0.14 & 1.19 \\
\hline
\end{tabular}

Moreover, the leached out metals such as $\mathrm{Al}, \mathrm{Ca}, \mathrm{Fe}, \mathrm{Na}$, and $\mathrm{Si}$ were compared against the initial concentration present in the mixture as shown in Table 7. It is clearly shown that $18.28 \%$ of $\mathrm{Na}$ leached out after five cycles. This may be attributed to the excess alkali content in the mixture. Furthermore, Fe has been observed to leach out in a minimal amount against its initial concentration. This clearly illustrates and gives us the conviction that the iron component of the material has been incorporated in the geopolymer matrix. This has also been demonstrated in the study conducted in [56] in which the geopolymeric gel resembles the typical compositions of poly(ferro-sialate-siloxo) and poly(ferro-sialate-disiloxo). 
On the other hand, the heavy metals leached, such as $\mathrm{Cd}, \mathrm{Cr}$, and $\mathrm{Pb}$, given the lower concentration leached out, indicates a lower solubility in the extractant. Immobilization of these heavy metals in a high-pH condition has been reported elsewhere [61,62]. Because these heavy metals are cationic species and the geopolymeric gel is basic in nature, an effective immobilization may have occurred [63]. However, the high concentration of leached-out arsenic (12.09 ppm) as compared with other heavy metals may indicate that it is mobile in a basic solution. The same results were obtained in [64] and [65], wherein heavy metals such as As were found to be more mobile in the basic environment. Arsenic in leachate exists as oxy-anions in two oxidation states namely arsenite $\left(\mathrm{AsO}_{3}{ }^{3-}\right)$ and arsenate $\left(\mathrm{AsO}_{4}{ }^{3-}\right)$. The former is considered to be more toxic. The mobility of As in a basic condition may be attributed to the co-existence of its oxy-anions in the $\mathrm{pH}$ range of 6-9 [66]. The same behavior of As has been reported in [63], wherein anionic species become leachable in a high-pH environment. The reduction in the concentration of As from $12.09 \mathrm{ppm}$ in the first cycle to $2.78 \mathrm{ppm}$ in the second cycle could mean a reduction in mobility. This may be attributed to the presence of a calcium compound in the geopolymer matrix. This is also in agreement with the study in [67], wherein the results showed that the presence of calcium could reduce the mobility of arsenic. The presence of calcium may result in the precipitation of highly insoluble calcium arsenate. Considering the natural basic environment of soil-fly ash geopolymer cement, further studies on the leaching behavior of arsenic are recommended.

Table 7. Percentage leached out of metals with respect to initial concentration.

\begin{tabular}{cccc}
\hline Metal & Initial Concentration (ppm) & $\begin{array}{c}\text { Cumulative Concentration after } \\
\mathbf{5} \text { Cycles }(\mathbf{p p m})\end{array}$ & Percentage Leached (\%) \\
\hline $\mathrm{Al}$ & 84,143 & 43 & 0.052 \\
$\mathrm{Ca}$ & 88,335 & 3 & 0.004 \\
$\mathrm{Fe}$ & 357,783 & 4 & 0.001 \\
$\mathrm{Na}$ & 42,120 & 7701 & 18.28 \\
$\mathrm{Si}$ & 237,957 & 33 & 0.014 \\
\hline
\end{tabular}

\section{Conclusions}

This study has evaluated the acid resistance and leachability of geopolymer from soil-fly ash mixture using a one-part geopolymer binder system. The following findings can be drawn:

1. The soil-fly ash geopolymer cement showed a promising result in terms of compressive strength considering that the strength further increased after acid exposure, from $1.0 \mathrm{MPa}$ (without immersion) to $2.6 \mathrm{MPa}$ (28-day immersion) and 3.2 $\mathrm{MPa}$ (56-day immersion). This indicates that the soil-fly ash geopolymer cement used in this study is an acid-resistant material that can be used as backfill/foundation.

2. The shift in peaks of FTIR spectra and decrease in peaks of XRD pattern between raw material and soil-fly ash geopolymer cement was found to be a manifestation of geopolymerization.

3. No deterioration was observed on the soil-fly ash geopolymer cement matrix as manifested in the result of UCS and SEM-EDX analysis. However, the formation of gypsum was observed on the samples, which indicate that the calcium compounds in the matrix reacted with the sulfates of the acidic medium.

4. Soil-fly ash geopolymer cement (SO-CFA) was dominantly composed of Na-rich gel. The coexistence of gel, sodium aluminosilicate hydrate ( $\mathrm{N}-\mathrm{A}-\mathrm{S}-\mathrm{H})$, and calcium (alumino) silicate hydrate $(\mathrm{C}(-\mathrm{A})-\mathrm{S}-\mathrm{H})$ on soil-fly ash geopolymer cement exposed to acidic conditions (SO-CFA-28) were observed.

5. High concentrations of $\mathrm{Al}, \mathrm{Na}$, and $\mathrm{Si}$ are attributed to a high initial content of $\mathrm{Al}, \mathrm{Na}$, and $\mathrm{Si}$ in the raw material and alkali activator content. The lower solubility of Fe may be attributed to the incorporation of the Fe in the geopolymer matrix. Ca leaching may support the presence of gypsum in the geopolymer matrix. The concentration of metals shows a decreasing pattern with 
contact time except for $\mathrm{Cd}$ and $\mathrm{Pb}$. A high concentration of As at the first cycle may indicate that it is more mobile in a basic solution as compared with other heavy metals.

Future works will investigate the long-term durability of the material. Sustainability assessment including cost analysis will also be done for large-scale geotechnical engineering applications.

Author Contributions: Conceptualization: A.A.S.T. and M.A.B.P.; data curation: A.A.S.T.; formal analysis: A.A.S.T., R.A.J.M., J.R.D., and D.E.C.Y.; supervision: J.R.D. and M.A.B.P.; writing—original draft: A.A.S.T. and M.A.B.P.; writing-review \& editing: R.A.J.M., D.E.C.Y., and M.A.B.P.

Funding: This research was primarily funded by Engineering Research and Development for Technology (ERDT), University Research Coordination Office Interdisciplinary Research, grant number URCO IR 1TAY15-3TAY16, and JSPS Bridge Fellowship Program, grant number BR171401.

Acknowledgments: The authors are also thankful for the support given by the management of CHED-PHERNet Sustainability program, the Chemical Engineering Laboratory, the Mechanical Engineering Laboratory, the Geotechnical Laboratory of De La Salle University (DLSU), International Development Engineering of Tokyo Institute of Technology (TIT), and the Advanced Device and Materials Testing Laboratory (ADMATEL) of Department of Science and Technology for allowing us to use their laboratory facilities during the conduct of the study. The authors also acknowledge the academic editor and reviewer for the comments and suggestions, which led to the improvement of the manuscript. Carlito Tabelin and Ivyleen Bernardo-Arugay are also acknowledged for their assistance in XRD data analysis.

Conflicts of Interest: The authors declare no conflict of interest.

\section{References}

1. Towards a Zero-Emission, Efficient, and Resilient Buildings and Construction Sector: Global Status Report 2017. 2017. Available online: http://www.worldgbc.org/sites/default/files/UNEP\%20188_GABC_en\% 20\%28web\%29.pdf (accessed on 15 May 2018).

2. Worrell, E.; Price, L.; Martin, N.; Hendriks, C.; Ozawa, M. L. Carbon Dioxide Emissions from the Global Cement Industry. Annu. Rev. Energ. Environ. 2001, 26, 303-329. [CrossRef]

3. Cement Manufacturers' Association of the Philippines Inc. (CeMAP) 2015 Annual Cement Industry Report; Technical Report; Cement Manufacturers' Association of the Philippines Inc. (CeMAP): Pasig City, Philippines, 2015.

4. Gallardo, S.; Dungca, J.; Gallardo, R.; Kalaw, M.E. Sustainability Issues Due to Coal Ash from Coal Fired Powerplants Phase 1: Impact Assessment of Coal Ash Dumping in a Typical Power Generating Facility; Interdisciplinary Research Final Report; University Research Coordination Office, De La Salle University: Manila, Philippines, 2012.

5. Coal Statistics. 2015. Available online: https://www.doe.gov.ph/energy-resources?q=energy-resources / coal-statistics (accessed on 19 September 2016).

6. Blissett, R.S.; Rowson, N.A. A review of the multi-component utilisation of coal fly ash. Fuel 2012, 97, 1-23. [CrossRef]

7. Zhang, Z.; Zhu, Y.; Yang, T.; Li, L.; Zhu, H.; Wang, H. Conversion of local industrial wastes into greener cement through geopolymer technology: A case study of high-magnesium nickel slag. J. Clean. Prod. 2017, 141, 463-471. [CrossRef]

8. Malenab, R.A.J.; Ngo, J.P.S.; Promentilla, M.A.B. Chemical Treatment of Waste Abaca for Natural Fiber-Reinforced Geopolymer Composite. Materials 2017, 10, 579. [CrossRef] [PubMed]

9. Promentilla, M.A.B.; Thang, N.H.; Trung Kien, P.; Hinode, H.; Bacani, F.T.; Gallardo, S.M. Optimizing Ternary-blended Geopolymers with Multi-response Surface Analysis. Waste Biomass Valoriz. 2016, 7, 929-939. [CrossRef]

10. Kalaw, M.E.; Culaba, A.; Hinode, H.; Kurniawan, W.; Gallardo, S.; Promentilla, M.A. Optimizing and Characterizing Geopolymers from Ternary Blend of Philippine Coal Fly Ash, Coal Bottom Ash and Rice Hull Ash. Materials 2016, 9, 580. [CrossRef] [PubMed]

11. Zawrah, M.F.; Gado, R.A.; Feltin, N.; Ducourtieux, S.; Devoille, L. Recycling and utilization assessment of waste fired clay bricks (Grog) with granulated blast-furnace slag for geopolymer production. Process Saf. Environ. Prot. 2016, 103 Pt A, 237-251. [CrossRef] 
12. Singh, B.; Ishwarya, G.; Gupta, M.; Bhattacharyya, S.K. Geopolymer concrete: A review of some recent developments. Constr. Build. Mater. 2015, 85, 78-90. [CrossRef]

13. Abdel-Gawwad, H.A.; Abo-El-Enein, S.A. A novel method to produce dry geopolymer cement powder. Hous. J. Build. Natl. Res. Cent. 2016, 12, 13-24. [CrossRef]

14. Ahmari, S.; Zhang, L. Utilization of cement kiln dust (CKD) to enhance mine tailings-based geopolymer bricks. Constr. Build. Mater. 2013, 40, 1002-1011. [CrossRef]

15. Ferone, C.; Colangelo, F.; Cioffi, R.; Montagnaro, F.; Santoro, L. Mechanical performances of weathered coal fly ash based geopolymer bricks. Procedia Eng. 2011, 21, 745-752. [CrossRef]

16. Xie, J.; Kayali, O. Effect of initial water content and curing moisture conditions on the development of fly ash-based geopolymers in heat and ambient temperature. Constr. Build. Mater. 2014, 67 Pt A, 20-28. [CrossRef]

17. Van Jaarsveld, J.G.S.; Van Deventer, J.S.J. The Potential Use of Geopolymeric Materials to Immobilise Toxic Metals: Part I. Theory and Applications. Miner. Eng. 1996, 10, 659-669. [CrossRef]

18. Zhang, M.; Guo, H.; El-Korchi, T.; Zhang, G.; Tao, M. Experimental feasibility study of geopolymer as the next-generation soil stabilizer. Constr. Build. Mater. 2013, 47, 1468-1478. [CrossRef]

19. Djobo, J.N.Y.; Elimbi, A.; Tchakouté, H.K.; Kumar, S. Mechanical properties and durability of volcanic ash based geopolymer mortars. Constr. Build. Mater. 2016, 124, 606-614. [CrossRef]

20. Peng, M.X.; Wang, Z.H.; Xiao, Q.G.; Song, F.; Xie, W.; Yu, L.C.; Huang, H.W.; Yi, S.J. Effects of alkali on one-part alkali-activated cement synthesized by calcining bentonite with dolomite and $\mathrm{Na}_{2} \mathrm{CO}_{3}$. Appl. Clay Sci. 2017, 139, 64-71. [CrossRef]

21. Provis, J. L. Activating solution chemistry for geopolymers. In Geopolymers; Provis, J.L., van Deventer, J.S.J., Eds.; Woodhead Publishing: Cambridge, UK, 2009; pp. 50-71, ISBN 978-1-84569-449-4.

22. Nematollahi, B.; Sanjayan, J.; Shaikh, F.U.A. Synthesis of heat and ambient cured one-part geopolymer mixes with different grades of sodium silicate. Ceram. Int. 2015, 41, 5696-5704. [CrossRef]

23. Luukkonen, T.; Abdollahnejad, Z.; Yliniemi, J.; Kinnunen, P.; Illikainen, M. One-part alkali-activated materials: A review. Cem. Concr. Res. 2018, 103, 21-34. [CrossRef]

24. Temuujin, J.; van Riessen, A.; Williams, R. Influence of calcium compounds on the mechanical properties of fly ash geopolymer pastes. J. Hazard. Mater. 2009, 167, 82-88. [CrossRef] [PubMed]

25. Jin, M.; Zheng, Z.; Sun, Y.; Chen, L.; Jin, Z. Resistance of metakaolin-MSWI fly ash based geopolymer to acid and alkaline environments. J. Non-Cryst. Solids 2016, 450, 116-122. [CrossRef]

26. Akar, G.; Polat, M.; Galecki, G.; Ipekoglu, U. Leaching behavior of selected trace elements in coal fly ash samples from Yenikoy coal-fired power plants. Fuel Process. Technol. 2012, 104, 50-56. [CrossRef]

27. Koukouzas, N.; Ketikidis, C.; Itskos, G. Heavy metal characterization of CFB-derived coal fly ash. Fuel Process. Technol. 2011, 92, 441-446. [CrossRef]

28. Ibrahim, I.A.A. Chemical characterization and mobility of metal species in fly ash-water system. Water Sci. 2015, 29, 109-122. [CrossRef]

29. Tigue, A.A.S.; Dungca, J.R.; Hinode, H.; Kurniawan, W.; Promentilla, M.A.B. Synthesis of a one-part geopolymer system for soil stabilizer using fly ash and volcanic ash. MATEC Web Conf. 2018, 156, 1-11. [CrossRef]

30. Pacheco-Torgal, F.; Jalali, S.; Gomes, J.P.C. Utilization of mining wastes to produce geopolymer binders. In Geopolymers; Provis, J.L., van Deventer, J.S.J., Eds.; Woodhead Publishing: Cambridge, UK, 2009; pp. 267-293, ISBN 978-1-84569-449-4.

31. Ahmari, S.; Zhang, L. The properties and durability of alkali-activated masonry units. In Handbook of Alkali-Activated Cements, Mortars and Concretes; Pacheco-Torgal, F., Labrincha, J.A., Leonelli, C., Palomo, A., Chindaprasirt, P., Eds.; Woodhead Publishing: Cambridge, UK, 2015; pp. 643-660.

32. Bakharev, T. Resistance of geopolymer materials to acid attack. Cem. Concr. Res. 2005, 35, 658-670. [CrossRef]

33. Avirneni, D.; Peddinti, P.R.T.; Saride, S. Durability and long term performance of geopolymer stabilized reclaimed asphalt pavement base courses. Constr. Build. Mater. 2016, 121, 198-209. [CrossRef]

34. Dungca, J.R.; Dychangco, L.F.T. Strength properties of road base materials blended with waste limestones. Int. J. Geomate 2016, 11, 2493-2498.

35. Zaimoglu, A.S. Optimization of unconfined compressive strength of fine-grained soils modified with polypropylene fibers and additive materials. KSCE J. Civ. Eng. 2015, 19, 578-582. [CrossRef] 
36. Allahverdi, A.; Najafi Kani, E. Construction Wastes as Raw Materials for Geopolymer Binders. Int. J. Civ. Eng. 2009, 7, 154-160.

37. Cullity, B.D.; Stock, S.R. Elements of X-Ray Diffraction: Pearson New International Edition; Pearson Education Limited: London, UK, 2013; ISBN 9781292052557.

38. Van Jaarsveld, J.G.S.; van Deventer, J.S.J.; Lukey, G.C. The characterisation of source materials in fly ash-based geopolymers. Mater. Lett. 2003, 57, 1272-1280. [CrossRef]

39. Association of Structural Engineers of the Philippines. National Structural Code of the Philippines 2010: Buildings, Towers and Other Vertical Structures, 6th ed.; Association of Structural Engineers of the Philippines: Quezon City, Philippines, 2010; ISBN 2094-5477.

40. Choobbasti, A.J.; Kutanaei, S.S. Microstructure characteristics of cement-stabilized sandy soil using nanosilica. J. Rock Mech. Geotech. Eng. 2017, 9, 981-988. [CrossRef]

41. Ojuri, O.O.; Adavi, A.A.; Oluwatuyi, O.E. Geotechnical and environmental evaluation of lime-cement stabilized soil-mine tailing mixtures for highway construction. Transp. Geotech. 2017, 10, 1-12. [CrossRef]

42. Ghobadi, M.H.; Abdilor, Y.; Babazadeh, R. Stabilization of clay soils using lime and effect of $\mathrm{pH}$ variations on shear strength parameters. Bull. Eng. Geol. Environ. 2014, 73, 611-619. [CrossRef]

43. Correia, A.A.S.; Rasteiro, M.G. Nanotechnology Applied to Chemical Soil Stabilization. Procedia Eng. 2016, 143, 1252-1259. [CrossRef]

44. Al-Mukhtar, M.; Khattab, S.; Alcover, J.F. Microstructure and geotechnical properties of lime-treated expansive clayey soil. Eng. Geol. 2012, 139, 17-27. [CrossRef]

45. Dash, S.; Hussain, M. Lime Stabilization of Soils: Reappraisal. J. Mater. Civ. Eng. 2012, 24, 707-714. [CrossRef]

46. Guo, X.; Shi, H.; Wei, X. Pore properties, inner chemical environment, and microstructure of nano-modified CFA-WBP (class C fly ash-waste brick powder) based geopolymers. Cem. Concr. Compos. 2017, 79, 53-61. [CrossRef]

47. Chen, L.; Wang, Z.; Wang, Y.; Feng, J. Preparation and Properties of Alkali Activated Metakaolin-Based Geopolymer. Materials 2016, 9, 767. [CrossRef] [PubMed]

48. Zhang, M.; Zhao, M.; Zhang, G.; Mann, D.; Lumsden, K.; Tao, M. Durability of red mud-fly ash based geopolymer and leaching behavior of heavy metals in sulfuric acid solutions and deionized water. Constr. Build. Mater. 2016, 124, 373-382. [CrossRef]

49. Chou, L.; Wollast, R. Study of the weathering of albite at room temperature and pressure with a fluidized bed reactor. Geochim. Cosmochim. Acta 1984, 48, 2205-2217. [CrossRef]

50. Oelkers, E.H.; Schott, J. Experimental study of anorthite dissolution and the relative mechanism of feldspar hydrolysis. Geochim. Cosmochim. Acta 1995, 59, 5039-5053. [CrossRef]

51. Koenig, A.; Herrmann, A.; Overmann, S.; Dehn, F. Resistance of alkali-activated binders to organic acid attack: Assessment of evaluation criteria and damage mechanisms. Constr. Build. Mater. 2017, 151, 405-413. [CrossRef]

52. Kuttah, D.; Sato, K. Review on the effect of gypsum content on soil behavior. Transp. Geotech. 2015, 4, $28-37$. [CrossRef]

53. Gunasekara, C.; Law, D.W.; Setunge, S.; Sanjayan, J.G. Zeta potential, gel formation and compressive strength of low calcium fly ash geopolymers. Constr. Build. Mater. 2015, 95, 592-599. [CrossRef]

54. Magiera, T.; Gołuchowska, B.; Jabłońska, M. Technogenic Magnetic Particles in Alkaline Dusts from Power and Cement Plants. Water Air Soil Pollut. 2013, 224, 1389. [CrossRef] [PubMed]

55. Kutchko, B.G.; Kim, A.G. Fly ash characterization by SEM-EDS. Fuel 2006, 85, 2537-2544. [CrossRef]

56. Kumar, S.; Yankwa Djobo, J.N.; Kumar, A.; Kumar, S. Geopolymerization behavior of fine iron-rich fraction of brown fly ash. J. Build. Eng. 2016, 8, 172-178. [CrossRef]

57. Khan, M.Z.N.; Shaikh, F.U.A.; Hao, Y.; Hao, H. Synthesis of high strength ambient cured geopolymer composite by using low calcium fly ash. Constr. Build. Mater. 2016, 125, 809-820. [CrossRef]

58. Walkley, B.; Provis, J.; San Nicolas, R.; Sani, M.A.; Van Deventer, J. Stoichiometrically controlled C(-A)-S-H/N-A-S-H gel blends via alkali activation of synthetic precursors. Adv. Appl. Ceram. 2015, 114, 372-377. [CrossRef]

59. Abdollahnejad, Z.; Hlavacek, P.; Miraldo, S.; Pacheco-Torgal, F.; Aguiar, J.L.B. de Compressive strength, microstructure and hydration products of hybrid alkaline cements. Mater. Res. 2014, 17, 829-837. [CrossRef]

60. Davidovits, J. Geopolymer Cement, a Review. 2013. Available online: https://www.geopolymer.org/ fichiers_pdf/GPCement2013.pdf (accessed on 15 May 2018). 
61. Zhang, J.; Provis, J.L.; Feng, D.; van Deventer, J.S.J. Geopolymers for immobilization of $\mathrm{Cr}^{6+}, \mathrm{Cd}^{2+}, \mathrm{and}^{2+}$. J. Hazard. Mater. 2008, 157, 587-598. [CrossRef] [PubMed]

62. Xu, H.; Gong, W.; Syltebo, L.; Izzo, K.; Lutze, W.; Pegg, I.L. Effect of blast furnace slag grades on fly ash based geopolymer waste forms. Fuel 2014, 133, 332-340. [CrossRef]

63. Yliniemi, J.; Pesonen, J.; Tiainen, M.; Illikainen, M. Alkali activation of recovered fuel-biofuel fly ash from fluidised-bed combustion: Stabilisation/solidification of heavy metals. Waste Manag. 2015, 43, 273-282. [CrossRef] [PubMed]

64. Ahmari, S.; Zhang, L. Durability and leaching behavior of mine tailings-based geopolymer bricks. Constr. Build. Mater. 2013, 44, 743-750. [CrossRef]

65. Sanusi, O.; Tempest, B.; Ogunro, V. Mitigating Leachability from Fly Ash Based Geopolymer Concrete Using Recycled Concrete Aggregate (RCA). In Proceedings of the Geo-Frontiers Congress 2011, Dallas, TX, USA, 13-16 March 2011; pp. 1315-1324.

66. Shankar, S.; Shikha, D.; Shanker, U. Arsenic Contamination of Groundwater: A Review of Sources, Prevalence, Health Risks, and Strategies for Mitigation. Sci. World J. 2014, 2014, 304524. [CrossRef] [PubMed]

67. Wang, T.; Wang, J.; Tang, Y.; Shi, H.; Ladwig, K. Leaching Characteristics of Arsenic and Selenium from Coal Fly Ash: Role of Calcium. Energy Fuels 2009, 23, 2959-2966. [CrossRef]

(c) 2018 by the authors. Licensee MDPI, Basel, Switzerland. This article is an open access article distributed under the terms and conditions of the Creative Commons Attribution (CC BY) license (http:/ / creativecommons.org/licenses/by/4.0/). 